\title{
Factors influencing Serrapinnus notomelas (Characiformes: Characidae) populations in upper Paraná river floodplain lagoons
}

\author{
Pitágoras Augusto Piana*, Luiz Carlos Gomes**, and Elimaida Mayo Cortez**
}

Identification of variables that influence fish populations is one of the main challenges in ecology. To explore this, data were collected quarterly from February 2000 to November 2001 using seines, along the shore of four isolated lagoons of the upper Paraná River floodplain. Serrapinnus notomelas was selected to assess the effect of abiotic and biotic variables using indirect gradient analysis. Abiotic variables were summarized by principal components analysis (PCA) and then the scores of the axis retained for interpretation were correlated with abundances of $S$. notomelas. Variables that best explained S. notomelas abundance were surface area of the lagoon, total suspended solids and Secchi depth (these last two, indirectly linked to predation). The most relevant biotic variable that determined population size of $S$. notomelas was predation.

A identificação das variáveis que influenciam nas densidades populacionais de peixes é um dos principais desafios em ecologia. Para explorar isto, assembléias de peixes foram amostradas trimestralmente de fevereiro de 2000 a novembro de 2001 com auxílio de redes de arrasto, operadas nas regiões marginais de quatro lagoas isoladas da planície de inundação do alto rio Paraná. Serrapinnus notomelas foi selecionada para avaliar o efeito de variáveis abióticas e bióticas através de análise indireta de gradientes. Variáveis abióticas foram sumarizadas numa análise de componentes principais (ACP) e os escores dos eixos retidos para interpretação foram então correlacionados com as abundâncias de $S$. notomelas. Área de superfície da lagoa, sólidos totais em suspensão e profundidade do disco de Secchi foram as variáveis que melhor explicaram a abundância de S. notomelas. Além disto, a predação, que é influenciada pela transparência da água, foi a interação biótica que apresentou maior relevância na determinação do tamanho populacional desta espécie.

Key words: population regulation, abiotic variables, competition, predation.

\section{Introduction}

Populations show variations in abundance as an adaptive response to changes in chemical, physical and biological characteristics of habitats (Pimm, 1991). In order to be regulated by any factor, a population should present: i) persistence, ii) abundance fluctuation threshold and, iii) tendency to return to a balance density (Hixon et al., 2002). Identification of the main factors involved in population regulation and the mechanisms acting is a great challenge of ecology. Regulation may be due to natural environment variability that affects birth and death rates. Then, populations are subjected to random fluctuations and therefore, susceptible to extinction.

A population in ideal conditions tends to grow geometrically. However, in natural environments, population growth may be limited by several variables and/or events (here named factors). Malthus and Darwin attributed to competition the primary effects on population regulation, in spite of possible effects of predation. The mechanism that would cause a de- crease in population growth rate by competition (density dependent) was explained by Verhulst in 1838 (sensu Gotelli, 2001 ) in the logistic equation. This equation defines a maximum limit for abundance of a given population, which depends on the carrying capacity. In a closed population, regulatory growth factors act directly on birth and death rates because there are no migrations. In such cases, factors acting under dependence of population density, such as predation and competition, are potentially sources of control (Hixon et al., 2002).

In general, abiotic and biotic factors affect population densities of species belonging to different trophic levels. However, the relative contribution of these factors to each trophic level may, possibly, be differentiated. Therefore, in this work, we attempt to identify possible regulatory mechanisms for the population density of Serrapinnus notomelas (Eigenmann, 1915). This species is algivorous, non migratory and does not develop parental care (Suzuki et al., 2004). Its life cycle is short, body size is small (usually less than $4.0 \mathrm{~cm}$ of total length), and may persist in a great variety of habitats

\footnotetext{
* Graduate Course in Inland Aquatic Environments. Department of Biology, Maringá State University. e-mail: pitapiana@yahoo.com.br ** Nucleus of Research in Limnology, Ichthyology and Aquaculture (Nupelia), Department of Biology, Maringa State University. Avenida Colombo 5790, 87020-900 Maringá, PR, Brazil.
} 
(Luiz et al., 1997). These characteristics prompt fast responses of the species to habitat variations concerning chemical, physical and biological factors. Thus, population growth can be studied in temporal scales compatible with the life cycle of a species. In this paper, we evaluate spatial and temporal variations in the abundance of $S$. notomelas populations from four lagoons (all isolated) of the upper Paraná River floodplain, in a period during which no flood occurred (closed populations). Specifically, we try to answer the following question: what is (are) the main factor(s) (abiotic: physical or chemical?; biotic: competition or predation?) that regulates abundance of $S$. notomelas populations in these lagoons?

\section{Material and Methods}

Study Area. The Paraná River is the tenth largest of the world in discharge, and the fourth in drainage area $\left(5.0 \times 10^{8} \mathrm{~m}^{3}\right.$ / year; $2.8 \times 10^{6} \mathrm{~km}^{2}$, respectively). It drains most of the centralsouthern part of South America, from the Andes to the Serra do Mar near the Atlantic Ocean.

The studied area corresponds to the upper third of the Paraná River (Bonetto, 1986) (Fig. 1). In this stretch, the last one inside Brazilian territory free of dams, there is an extensive floodplain on the west margin. This floodplain supports a great diversity of organisms (Agostinho et al., 2000). Main impacts in the region are high biocide loads and pollution from domestic and agricultural activities, deforestation of riparian vegetation and, the most conspicuous, construction of dams. Dams have altered the natural water regime (floods) and removed portions of floodplains in the upper Paraná River basin. The remaining floodplain is a mosaic of habitats, with several canals and lagoons (connected or isolated). Isolated lagoons are heterogeneous in surface area, depth, distance from the main river, macrophyte cover and other features (Table 1).

Sampling. Fish samplings were carried out with seines $(20 \mathrm{~m}$ long; mesh size $0.8 \mathrm{~cm}$ opposite knots), in shore areas of the four isolated lagoons of the upper Paraná River floodplain, operated quarterly from February 2000 to November 2001 (in this period, there was no flood). All captured individuals were taken to the laboratory, where they were counted and measured (total and

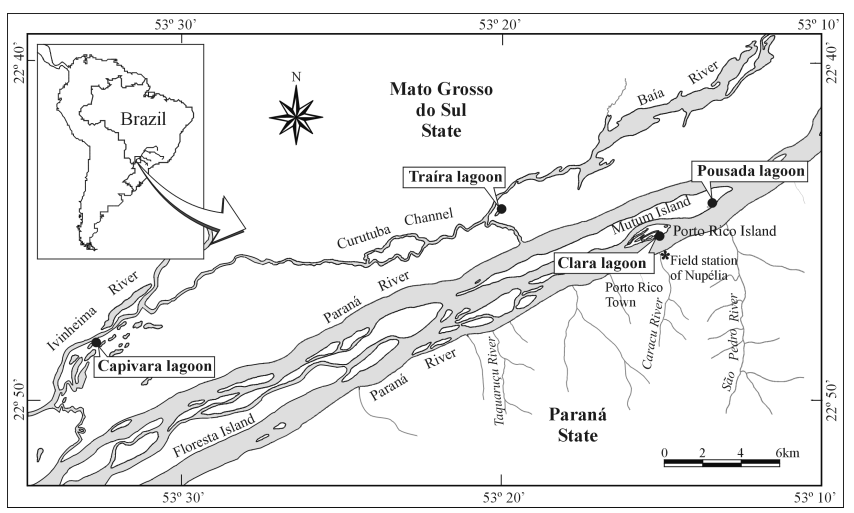

Fig. 1. Map of the upper Paraná River floodplain showing the locations of the sampling stations (lagoons). standard length). Abundances in the lagoons were expressed in number of individuals $/ 100 \mathrm{~m}^{2}$ of seined area.

Chemical [dissolved oxygen (mg/l), total phosphorus $(\mu \mathrm{g} /$ $1)$, dissolved phosphorus $(\mu \mathrm{g} / \mathrm{l})$, orto-phosphate $(\mu \mathrm{g} / \mathrm{l})$, nitrate $(\mu \mathrm{g} / \mathrm{l})$, nitrite $(\mu \mathrm{g} / \mathrm{l})$, ammonia $(\mu \mathrm{g} / \mathrm{l})$, dissolved organic carbon (ppm), alkalinity ( $\mu$ eq/1), conductivity $(\mu \mathrm{S} / \mathrm{cm})$, chlorophyll- $a(\mu \mathrm{g} / \mathrm{l})$ and $(\mathrm{pH})]$ and physical characteristics [area of the lagoon (ha), depth (m), turbidity (FTU), temperature $\left({ }^{\circ} \mathrm{C}\right)$, Secchi disk depth $(\mathrm{cm})$, total suspended solids $\left.(\mathrm{mg} / \mathrm{l})\right]$ of the lagoons, here denominated abiotic variables, were collected simultaneously and analyzed, later, by the physicochemical laboratory of the Nucleus of Research in Limnology, Ichthyology and Aquaculture - Nupelia.

Data Analyses. To identify the most important physical and chemical variables that could be influencing populations of $S$. notomelas, we adopted a multivariate approach (Gauch, 1986). We first summarized data in two principal components analysis (PCA), one for chemical and another for physical variables (data were $\log _{10}$ transformed in order to linearize relationships) using the software PC-ORD (McCune \& Mefford, 1997). The Broken Stick model was used as criteria to retain PCA axis for interpretation (Jackson, 1993). Scores of the axis retained for interpretation were correlated against abundance of $S$. notomelas [if not linear, abundance was $\log _{10}(\mathrm{x}+1)$ transformed]. In case of significant correlations $(P<$ $0.05)$, it is assumed that the variables with larger eigenvectors (coefficients of structure or correlations) for the axis are the ones that most influenced the abundance of the species.

In order to evaluate the effect of the biotic variables (competition and predation) on the populations of $S$. notomelas (voucher specimens deposited in the Museu de Ictiologia of Nupélia under the code NUP3210), abundance of fish species that are potentially competitors (Apareiodon affinis - voucher specimens code in Nupelia: NUP349, Astyanax altiparanae: NUP322, Aphyocharax anisitsi: NUP358, Astyanax fasciatus: NUP322, Aphyocharax sp.: NUP3225, Astyanax schubarti: NUP34, Brachyhypopomus cf. pinnicaudatus: NUP2510, Bryconamericus stramineus: NUP343, Characidium aff. zebra: NUP348, Crenicichla britskii: NUP345, Characidium sp.: NUP2352, Cyphocharax modestus: NUP3290, Cyphocharax nagelii: NUP431, Gymnotus spp.: NUP3166, Hyphessobrycon eques: NUP1503, Hoplosternum litoralle: NUP334, Hemigrammus marginatus: NUP392, Laetacara sp.: NUP352,

Table 1. Physical characteristics of the lagoons sampled in the upper Paraná River floodplain.

\begin{tabular}{lcccc}
\hline & \multicolumn{4}{c}{ Lagoons } \\
\hline Characteristic & Capivara & Traíra & Pousada & Clara \\
\hline Mean depth (m) & 3.6 & 2.1 & 0.40 & 1.2 \\
Length (m) & 750 & 110 & 860 & 360 \\
Perimeter (m) & 1700 & 290 & 2908 & 780 \\
Area (ha) & 7.2 & 0.47 & 12.7 & 0.91 \\
$\begin{array}{l}\text { Distance from the } \\
\text { main river (m) }\end{array}$ & 80 & 350 & 100 & 15 \\
\hline
\end{tabular}


Liposarcus anisitsi: NUP1529, Leporinus sp.: NUP763, Leporinus lacustris: NUP338, Leporinus obtusidens: NUP275, Loricariichthys platymetopom: NUP445, Metynnis maculatus: NUP443, Moenkhausia intermedia: NUP57, Moenkhausia sanctaefilomenae: NUP346, Odontostilbe sp.: NUP1517, Pyrrhulina australis: NUP344, Pimelodella sp. 1: NUP3455, Prochilodus lineatus: NUP330, Pimelodus maculatus: NUP320, Roeboides paranensis: NUP351, Schizodon borellii: NUP435, Steindachnerina brevipinna: NUP3179, Serrapinnus sp. 1: NUP3283, Serrapinnus sp. 2: NUP3455, Steindachnerina insculpta: NUP339, Sternopygus macrurus: NUP2096, Synbranchus marmoratus: NUP320, Satanoperca pappaterra: NUP422) were added and, then, scatterplots made to evaluate the kind of the relationship. Similarly, abundances of all fish species with potential to feed on S. notomelas (predators: Acestrorhynchus lacustris (voucher specimens code in Nupelia: NUP4), Astronotus crassipinnis (voucher specimens code in Nupelia: NUP3449), Cichla monoculus (voucher specimens code in Nupelia: NUP412), Cichlasoma paranaense (voucher specimens code in Nupelia: NUP109), Hoplias malabaricus (voucher specimens code in Nupelia: NUP265), Hoplerythrinus unitaeniatus (voucher specimens code in Nupelia: NUP61) e Serrassalmus marginatus (voucher specimens code in Nupelia: NUP395)) were also added and compared graphically with its density. For both group formations, we used data on diet composition
(Agostinho et al., 1997; Hahn et al., 1997, 2004; Luiz et al., 1998; Silva, 2002). Then, tendencies of the scatterplots were observed and, when possible, regression models were adjusted (linear or non-linear) to explain the relationship.

\section{Results}

Spatial and Temporal Variations in Abundance. In the period of study (February 2000 to November 2001), 68 fish species were captured, and $S$. notomelas was among the dominant species with great abundance, especially in Clara and Pousada lagoons, where densities increased over time, but with high variability in the end of the study. In Traíra and Capivara lagoons, for instance, densities decreased over time (Figs. 2a-d).

Influence of Abiotic Variables. Abiotic variables were summarized through principal components analysis (PCA) and the axes retained for interpretation were correlated against the abundance of $S$. notomelas.

For the PCA applied to chemical variables, four axis were retained for interpretation (they presented eigenvalues greater than the Broken-Stick eigenvalues) and together they explained almost $60 \%$ of total data variability. Eigenvectors (structure coefficients or correlations) demonstrate the variables that more contributed to formation of an axis and, consequently, in the ordination. For axis 1 (PC1), these variables were dissolved phos-
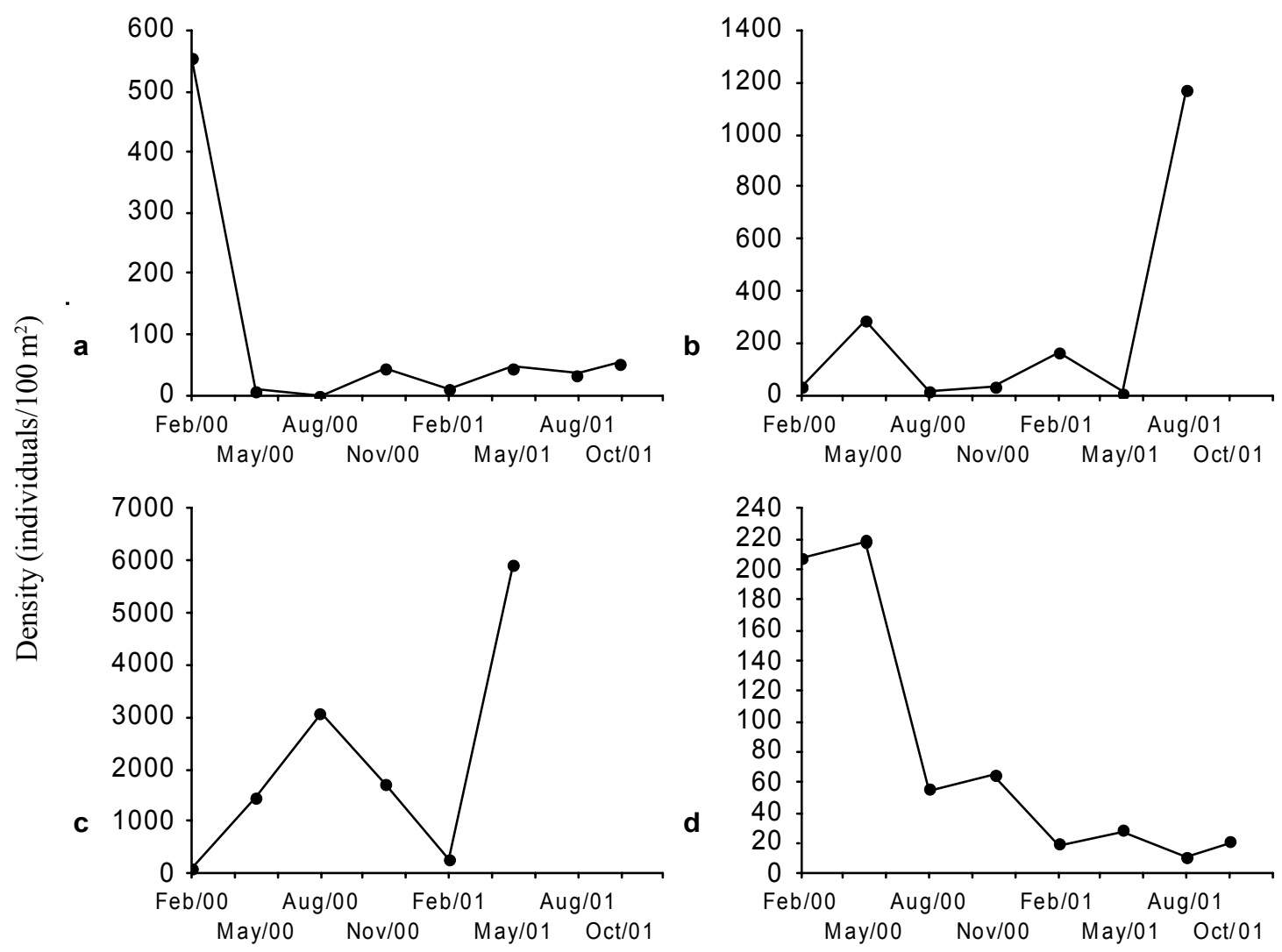

Figs. 2a-d. Temporal variation in the abundance of Serrapinnus notomelas in lagoons Capivara (a), Clara (b), Pousada (c) and Traíra (d). 
Table 2. Results of principal components analysis (PCA) applied for chemical variables.

\begin{tabular}{lcccc}
\hline Variables & Axis 1 & Axis 2 & Axis 3 & Axis 4 \\
\hline Eigenvalues & 3.198 & 3.006 & 2.497 & 1.680 \\
(explanation \%) & $(24.5)$ & $(23.1)$ & $(19.2)$ & $(12.9)$ \\
Broken-Stick eigenvalues & 3.180 & 2.180 & 1.680 & 1.347 \\
$\mathrm{pH}$ & 0.032 & 0.286 & -0.102 & 0.576 \\
Conductivity & -0.220 & 0.320 & 0.384 & 0.123 \\
Alkalinity & -0.111 & 0.136 & 0.523 & 0.014 \\
Dissolved oxygen & 0.166 & 0.135 & -0.475 & 0.126 \\
Chlorophyll- $a$ & -0.218 & -0.410 & 0.148 & 0.161 \\
Nitrite & 0.076 & 0.002 & -0.362 & -0.482 \\
Nitrate & -0.238 & -0.440 & -0.069 & 0.247 \\
Ammonia & -0.269 & -0.452 & -0.065 & 0.046 \\
Total nitrogen & -0.094 & 0.164 & -0.209 & 0.361 \\
Total phosphorus & -0.372 & 0.294 & -0.009 & -0.331 \\
Dissolved phosphorus & -0.470 & 0.224 & -0.053 & -0.166 \\
Orto-phosphate & -0.466 & -0.095 & -0.169 & -0.089 \\
Dissolved organic carbon & -0.380 & 0.202 & -0.326 & 0.201 \\
\hline
\end{tabular}

phorus and orto-phosphate, both negatively. For PC2, conductivity showed positive correlation, whereas ammonia, nitrate and chlorophyll- $a$ presented negative correlations. For PC3, alkalinity presented the larger positive correlation and dissolved oxygen the most negative. Finally, for PC4, pH was more correlated positively, whereas nitrite more negatively (Table 2 ).

For physical variables the first two PCA axes were retained for interpretation, based on the Broken Stick model. They together explained $63.5 \%$ of the total variability of the data matrix. Great eigenvectors were, for axis 1, Secchi depth (positively) and area of the lagoon and total suspended solids (negatively). For axis 2, turbidity (positive) and temperature (negative) were the variables with greater correlations (Table 3 ).

Scores of the axes retained for interpretation were generated and plotted against abundances of $S$. notomelas [transformed in $\log (\mathrm{x}+1)]$. Only scores of the axis 1 of the PCA that summarized physical variables presented significant Pearson correlation $(\mathrm{r}=-0.46 ; P<0.05)$ with the abundance of the species (Table 4). Therefore, it can be inferred that, for the

Table 3. Results of principal components analysis (PCA) applied for physical variables.

\begin{tabular}{lcc}
\hline Variables & Axis 1 & Axis 2 \\
\hline Eigenvalues (explanation \%) & $2.577(43.0)$ & $1.233(20.5)$ \\
Broken-Stick eigenvalues & 2.450 & 1.150 \\
Area & -0.482 & -0.345 \\
Lagoon depth & 0.348 & 0.142 \\
Temperature & 0.248 & -0.689 \\
Secchi depth & 0.485 & 0.109 \\
Turbidity & -0.375 & 0.560 \\
Total suspended solids & -0.457 & -0.245 \\
\hline
\end{tabular}

studied lagoons, abiotic factors that more influenced abundance of $S$. notomelas were the area of the lagoon, total suspended solids and Secchi depth (Table 4 and Fig. 3).

Influence of Biotic Variables. Relationship between abundance of $S$. notomelas and abundance of its competitors was positive (Fig. 4a). A quadratic model with significant parameters $(P<0.05)$ accounted for $93 \%$ of variation in $S$. notomelas populations. For piscivores species, as larger their abundance, lower the densities of S. notomelas (Fig. 4b). However it was neither possible to adjust a model to explain this relationship, nor explain it due to a significant correlation (Spearman: $\mathrm{r}=-0.10, P=0.65$ ).

\section{Discussion}

High abundances of $S$. notomelas in isolated lagoons of the upper Paraná River, as well as of other small bodied species is in part due to their opportunistic life strategy (sensu Winemiller, 1989), i.e., they present multiple spawning and mature quickly.

All variables considered in this study, i.e., abiotic variables, competition and predation, may somehow affect, directly or indirectly, fish populations (Matthews, 1998; Hixon et al., 2002). In the upper Paraná River floodplain, the flood pulse promotes homogenization of abiotic variables (Thomaz et al., 1992, 1997; Agostinho et al., 2000). With the end of the flood, lagoons are isolated and, every one of them, depending on their physiography, present characteristic values of abiotic variables. As time increases since inundation, these variables become more restrictive and, therefore, may determine composition and structure of fish assemblages.

Abundance of $S$. notomelas was greater in lagoons with larger surface area and with greater loads of total suspended solids (Pousada lagoon) and, it was lower in lagoons with smaller values of these variables and greater Secchi depth, i.e., cleaner waters (Traíra lagoon, for instance). These results are biologically relevant because larger environments usually present larger heterogeneity of habitats that can sup-

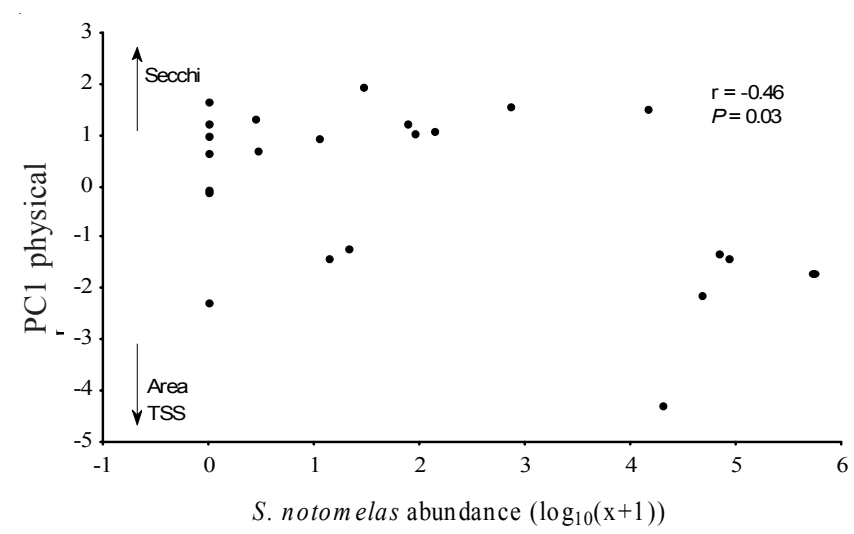

Fig. 3. Scatterplot of the abundance of Serrapinnus notomelas and the scores of axis 1 of the principal components analysis (PCA) that summarized physical variables. Variables that more contributed to formation of the axis (arrows) are also given. TSS $=$ Total suspended solids. 
port more species and greater abundances (Krebs, 1994).

The other two variables that apparently influenced $S$. notomelas populations work antagonistically, i.e., when total suspended solids is high, Secchi depth is low, resulting in darker water and hindering predation (Matthews, 1998). Okada et al. (2003) identified that the amount of piscivores fishes in a lagoon is an important variable determining structure of fish assemblages. Thus it is possible that predators find difficulties to prey when Secchi depth is low.

These findings differ slightly from others presented in the literature. In the review of Jackson et al. (2001), the most important variables structuring fish assemblages were $\mathrm{pH}$ and dissolved oxygen. It is reasonable to consider that the scale of their study was regional and they considered all species. For this study, the scale was more local and only a single species was analyzed. Therefore, in our scale of study, $\mathrm{pH}$ and dissolved oxygen did not present wide variations, and in most cases, they were not restrictive for fish, including $S$. notomelas.

Other studies developed in the upper Paraná River floodplain identified macrophyte cover and dissolved oxygen as the main factors explaining fish assemblages composition and structure (Veríssimo, 1994; Okada et al., 2003). In this study, quantity of macrophyte cover was not available to be related with the abundance of the species. However, macrophyte
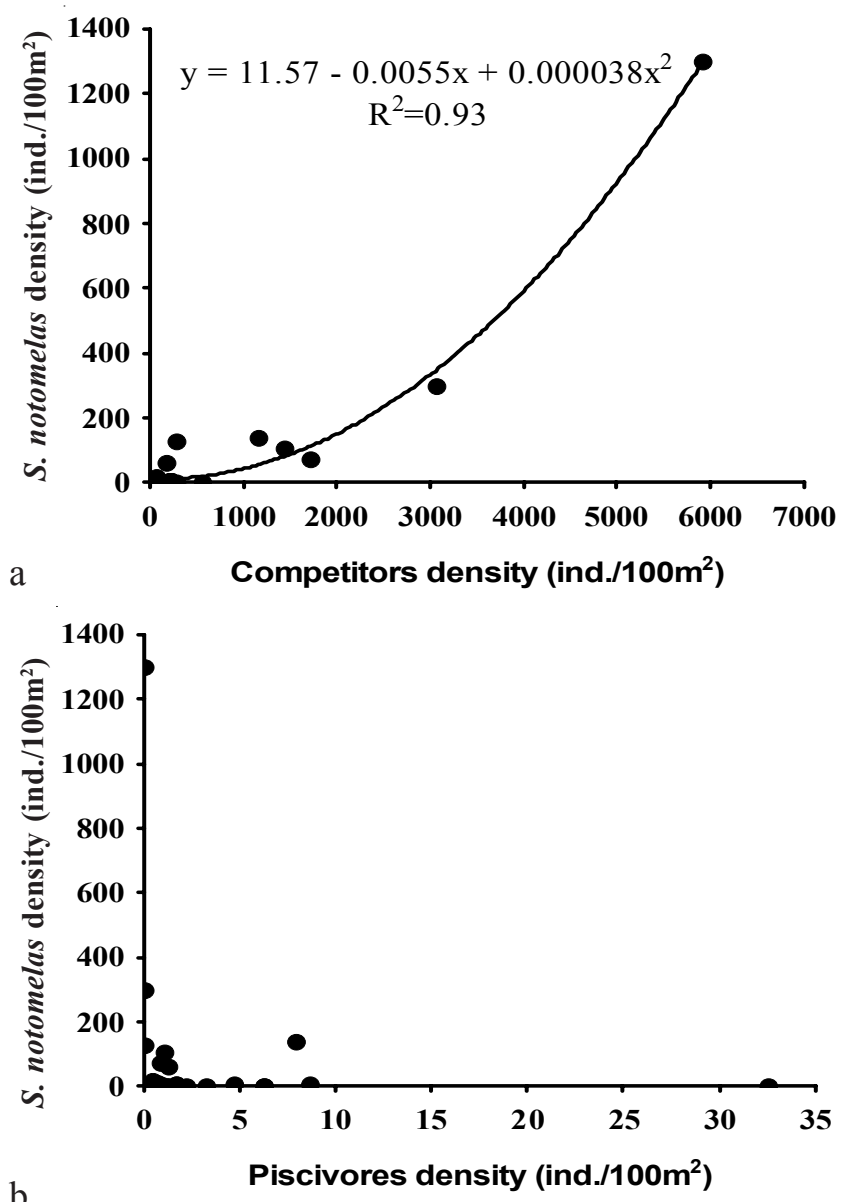

Figs. 4a-b. Relationship between densities of Serrapinnus notomelas and densities of competitors (a) and piscivores (b).
Table 4. Pearson and Spearman correlations (r) between the abundance of Serrapinnus notomelas [transformed in $\log _{10}$ $(\mathrm{x}+1)]$ and axes retained for interpretation of the principal components analysis (PCA) applied for chemical and physical variables. $P$ is the probability of finding a larger $r$.

\begin{tabular}{ccccc}
\hline PCA Axes & $\mathrm{r}$ (Pearson) & $P$ & $\mathrm{r}$ (Spearman) & $P$ \\
\hline PC1 chemical & -0.03 & 0.88 & -0.06 & 0.77 \\
PC2 chemical & -0.28 & 0.20 & -0.15 & 0.50 \\
PC3 chemical & 0.33 & 0.12 & 0.25 & 0.26 \\
PC4 chemical & 0.08 & 0.72 & 0.10 & 0.66 \\
PC1 physical & -0.46 & 0.03 & -0.24 & 0.26 \\
PC2 physical & -0.07 & 0.75 & -0.05 & 0.84 \\
\hline
\end{tabular}

might have influenced total suspended solids, and, they are, therefore, fundamental to explain the abundance of several species of fish, especially juveniles (Agostinho et al., 2003).

With respect to biotic variables, the positive relationship between abundance of $S$. notomelas and its competitors evidences that inter-specific competition is not the main factor that determines size of its populations in the studied lagoons. If it was, the relationship should be inverse. This fact can be explained because competition becomes evident when food resources are scarce (Matthews, 1998), and this is not the case of the lagoons on the studied period, except when in early phase of desiccation (Agostinho et al., 2000, 2004; Okada et al., 2003).

In floodplains, the high species diversity in lagoons is determined and influenced directly by variations in water level (Junk et al., 1989; Neiff, 1990). Therefore, water level and local topography regulate changes among biotopes and, after isolation, biotic interactions (predation and competition) are important factors in structuring fish assemblages (Matthews, 1998; Jackson et al., 2001). For the studied lagoons, predation appeared to be the stronger interaction, as mentioned by Petry et al. (2003a, 2003b) and Okada et al. (2003) who studied the same area.

\section{Conclusion}

In the four studied lagoons, alterations in the density of $S$. notomelas were apparently due to variations in abiotic and biotic variables resulted from the lack of a flood pulse during the period studied. Abiotic variables related to the density of the species, i.e., that controlled its population, were surface area of the lagoon, amount of total suspended solids and Secchi depth (these last two, indirectly linked to predation). The most relevant biotic variable that appears to influence population sizes of $S$. notomelas was predation, and this may be the case for all small sized species that inhabit lagoons.

\section{Acknowledgements}

We thank the Brazilian Long Term Ecological Research (Programa Ecológico de Longa Duração - PELD) site 6 for financing this research. We also thank the Nucleus of Research in Limnology, Ichthyology and Aquaculture (Nupelia) of the Maringa State University by the infrastructure to conduct the research. 


\section{Literature Cited}

Agostinho, A. A., N. S. Hahn, L. C. Gomes \& L. M. Bini. 1997. Estrutura trófica. Pp. 229-248. In: Vazzoler, A. E. A. M., A. A. Agostinho \& N. S. Hahn (Eds). A Planície de Inundação do Alto Rio Paraná: Aspectos Físicos, Biológicos e Socioeconômicos. Eduem, Maringá, 460p.

Agostinho, A. A., S. M. Thomaz, C. V. Minte-Vera \& K. O. Winemiller. 2000. Biodiversity in the high Paraná river floodplain. Pp. 89-118. In: Gopal, B., W. J. Junk \& J. A. Davis (Eds). Biodiversity in wetlands: assessment, function and conservation. Leiden, Backhuys Publishers, v.1, 353p.

Agostinho, A. A., L. C. Gomes \& H. F. Julio Jr. 2003. Relações entre macrófitas aquáticas e fauna de peixes. Pp. 261-279. In: Thomaz, S. M. \& L. M. Bini (Eds). Ecologia e manejo de macrófitas aquáticas. Maringá, Eduem, 341p.

Agostinho, A. A., L. C. Gomes, S. Veríssimo \& E. K. Okada. 2004. Flood regime, dam regulation and fish in the Upper Paraná river: effects on assemblage attributes, reproduction and recruitment. Reviews in Fish Biology and Fisheries, 14: 11-19.

Bonetto, A. A. 1986. The Paraná river system. Pp. 541-555. In: Davies, B. R. \& K. F. Walker (Eds). The ecology of river systems. Dordrecht, Dr. W. Junk Publishers, 793p.

Gauch, H. G. 1986. Multivariate analysis in community ecology. Cambridge, Cambridge University Press, 298p.

Gotelli, N. J. 2001. A Primer of Ecology, Third Edition. Massachusetts, Sinauer Associates, 265p.

Hahn, N. S., I. F. Andrian, R. Fugi \& V. L. L. Almeida. 1997. Ecologia trófica. Pp. 209-228. In: Vazzoler, A. E. A. M., A. A. Agostinho \& N. S. Hahn (Eds). A Planície de Inundação do Alto Rio Paraná: Aspectos Físicos, Biológicos e Socioeconômicos. Eduem, Maringá, 460p.

Hahn, N. S., R. Fugi \& I. F. Andrian. 2004. Trophic ecology of the fish assemblages. Pp. 247-269. In: Thomaz, S. M., A. A. Agostinho \& N. S. Hahn (Eds). The upper Paraná River and its floodplain: physical aspects, ecology and concervation. Backhuys Publishers, Leiden, 393p.

Hixon, M. A., S. W. Palaca \& S. A. Sandin. 2002. Population regulation: historical context and contemporary challenges of open vs. closed systems. Ecology, 83(6): 1490-1508.

Jackson, D. A. 1993. Stopping rules in principal component analysis: a comparison of heuristical and statistical approaches. Ecology, 74(8): 2204-2214.

Jackson, D. A., P. R. Peres Neto \& J. D. Olden. 2001. What controls who is where is fresh water fish communities - the roles of biotic, abiotic, and spatial factors. Canadian Journal of Fisheries and Aquatic Sciences, 58: 157-170.

Junk, W. J., P. B. Bayley \& R. E. Sparks. 1989. The flood pulse concept in river-floodplain systems. Canadian Journal of Fisheries and Aquatic Sciences, 106: 110-127.

Krebs, C. J. 1994. Ecology: The Experimental Analysis of Distribution and Abundance, Fourth Edition. New York, Harper Collins College Publishers, 801p.

Luiz, E. A., A. A. Agostinho, L. C. Gomes \& N. S. Hahn. 1998. Ecologia trófica de peixes em dois riachos da bacia do rio Paraná. Revista Brasileira de Biologia, 58(2): 273-285.
Matthews, W. J. 1998. Patterns in freshwater fish ecology. New York, Chapman \& Hall, 756p.

McCune, B. \& M. S. Mefford. 1997. Pc-Ord. Multivariate analysis of ecological data. Version 2.0. MjM Software Design. Gleneden Beach, Oregon, U.S.A.

Neiff, J. J. 1990. Ideas para la interpretacion ecológica del Paraná. Interciencia, 15(6): 424-441.

Okada, E. K., A. A. Agostinho, M. Petrere \& T. Penczak. 2003. Factors affecting fish diversity and abundance in drying ponds and lagoons in the upper Paraná River basin. Ecohydrology \& Hydrobiology, 3(1): 97-110.

Petry, A. C., A. A. Agostinho \& L. C. Gomes. 2003a. Fish assemblages of tropical floodplain lagoons: exploring the role of connectivity in a dry year. Neotropical Ichthyology, 15(4): 111-119.

Petry, A. C., A. A. Agostinho \& L. C. Gomes. 2003b. Spatial variation of the assemblage structure from the upper Rio Paraná floodplain, Brazil, in a dry year. Acta Limnologica Brasiliense, 15(1): 1-13.

Pimm, S. L. 1991. The balance of nature? Ecological issues in the conservation of species and communities. Chicago, The University of Chicago Press, 434p.

Silva, V. L. B. 2002. Ecologia alimentar de Cheirodon stenodon e Serrapinnus notomelas (Characiformes, Cheirodontinae) na região de desembocadura do rio Paranapanema na represa de Jurumirim, São Paulo. Unpublished Ph.D. Dissertation, Universidade Estadual Paulista, Botucatu. 105p.

Suzuki, H. I., F. M. Pelicice, E. A. Luiz, J. D. Latini \& A. A. Agostinho. 2004. Reproductive strategies of the fish community of the upper Paraná River floodplain. Pp. 125-130. In: Agostinho, A. A., L. Rodrigues, L. C. Gomes, S. M. Thomaz \& L. E. Miranda (Eds) Structure and functioning of the Paraná River and its floodplain: LTER - Site 6 (PELD - Sítio 6). Maringá, Eduem, 275p.

Thomaz, S. M., F. A. Lansac-Tôha, M. C. Roberto, F. A. Esteves \& A. F. Lima. 1992. Seasonal variation of some limnological factors of lagoa do Guaraná, a várzea lake of the High Rio Paraná, State of Mato Grosso do Sul, Brazil. Revue d'Hydrobiologie Tropicale, 25(4): 269-276.

Thomaz, S. M., M. C. Roberto \& L. M. Bini. 1997. Caracterização limnológica dos ambientes aquáticos e influência dos níveis fluviométricos. Pp. 73-102. In: Vazzoler, A. E. A. M., A. A. Agostinho \& N. S. Hahn (Eds). A planície de inundação do alto rio Paraná: aspectos físicos, biológicos e socio-econômicos. Maringá, Eduem, 460p.

Veríssimo, S. 1994. Variações na composição da ictiofauna em três lagoas sazonalmente isoladas, na planície de inundação do alto rio Paraná, ilha de Porto Rico, PR-Brasil. Unpublished Master Dissertation, Universidade Federal de São Carlos, São Carlos. 77p.

Winemiller, K. O. 1989. Patterns of variation on life history among South American fishes in seasonal environments. Oecologia, 81: 225-241.

Received July 2005 Accepted January 2006 